\title{
Educational Robotics and the Gender Perspective
}

\author{
Daniela Bagattini, Beatrice Miotti, and Fiorella Operto
}

\begin{abstract}
In this paper we explore the role of stereotypes in educational choices. Data on secondary school enrollments show that girls are abandoning STEM subjects. There are many reasons for this, including social and family expectations, but also the perception that jobs and careers in technical and scientific sectors will make it hard to take care of a family. This is an important theme for the future. The number of jobs in ICT will increase, and the low quantities of women in these sectors will have a strong impact on the availability of skilled workers, as well as increasing the gender gap. What is the role of school in this context? What activities can get more girls interested in science? We focus, in particular, on how innovative approaches such as educational robotics can help girls engage with STEM subjects, as happened with the "Roberta" project, whose results will be illustrated in this work.
\end{abstract}

Keywords Coding $\cdot$ Educational robotics $\cdot$ STEM $\cdot$ Stereotypes $\cdot$ Gender perspective

\section{What About the Gender Perspective?}

One of the first objections we are used to hearing to this question is: "Isn't school already egalitarian? $82 \%$ of Italian teachers are female".

While this may be true, a high female representation does not automatically mean there is a special focus on gender issues.

\footnotetext{
D. Bagattini $(\varangle) \cdot$ B. Miotti

Istituto Nazionale di Documentazione, Innovazione e Ricerca Educativa (Indire), Firenze, Italy

e-mail: d.bagattini@indire.it

B. Miotti

e-mail: b.miotti@indire.it

F. Operto

Scuola Di Robotica, Genova, Italy

e-mail: operto@scuoladirobotica.it
} 
Table 1 Percentage of female students by type of upper secondary school

\begin{tabular}{l|l}
\hline Upper secondary school type & Girls \\
\hline Music and dance; dance section & 90.6 \\
\hline Human sciences & 88.6 \\
\hline Languages & 78.3 \\
\hline Human sciences—social economy option & 71.1 \\
\hline Classics & 70.1 \\
\hline Art & 70.0 \\
\hline European/international & 66.7 \\
\hline Technical institute—economics section & 52.6 \\
\hline Science & 48.9 \\
\hline Music and dance; dance section & 47.6 \\
\hline Vocational & 43.7 \\
\hline Vocational—3 years (IeFP) & 34.9 \\
\hline Science—applied science option & 32.8 \\
\hline Science—sports section & 29.9 \\
\hline Technical institute—technology section & 16.9 \\
\hline
\end{tabular}

Source Ministry of Education, University, Research, https://dati. istruzione.it/opendata/

If we go back to degree courses by gender, we see that only $24 \%$ of teachers of technology subjects are female. This is the result of vertical segregation, which has continued through the years. Even in 2017/18, enrolments in upper secondary schools were heavily sectorialized by gender. (Table 1 ).

When we look at university careers, again we see gender differences in the various macro-areas, and even wider gaps on certain courses (Table 2).

On some degree courses within these macro-areas, the differences between the genders are even greater. For example, $75 \%$ of the teaching staff on the "Healthcare, nursing and midwifery" course (L/SNT1) are women.

Healthcare, however, is the area that has seen most change.

Science faculties are where the greatest differences are recorded (as are the humanities for males). The percentage of female students on the "Computer Science and Technology" degree, which includes courses in information science, and computer

Table 2 Percentage of women in university macro-areas

\begin{tabular}{l|l}
\hline University macro-area & Female $(\%)$ \\
\hline Humanities & 78.8 \\
\hline Healthcare & 69.5 \\
\hline Sociology & 55.7 \\
\hline Science & 37.9
\end{tabular}

Source Ministry of Education, University, Research, http://ana grafe.miur.it/index.php 
technology, is $12 \%$, whereas $21 \%$ of the students on the "Information Engineering" degree-which includes courses in electronic engineering, computer engineering, automation engineering, information engineering, etc.-are women.

Thus, there are still strong divisions, defined as "segregations" in educational choices, not because they are imposed, but, as analysis shows, because they are selflimitations on the range of possibilities. In these self-limitations, however, context and formal and informal guidance systems play a crucial role, particularly the expectations of parents and peer groups, but also those of the school system itself, and of career guidance. The gender perspective should also be taken into account in guidance actions.

A recent survey by Biemmi [1] investigated the motivations and paths of girls and boys enrolled in courses in which they are in the minority. Two very different universes emerge from the survey: for males, the decision to pursue a career in care is made for reasons that are endogenous to the school system and, often, it is a "second choice". Boys come to be there after starting other types of work or educational pathways, perhaps having come into contact with that type of work by chance. This is important for the success of training.

Girls on science courses, on the other hand, appear to be more determined. For some, choosing this type of path is almost a challenge. In general, these girls perform well at school and are less swayed by stereotypes, even if they wonder whether they will be able to reconcile their personal lives with their careers.

These girls have chosen to swim against the tide.

\section{Why Talk About Gender Perspective and Educational Robotics?}

The data in Tables 1 and 2 relate to enrollment in secondary schools and universities, which girls choose at an age when they and their families are already considering their future social aspirations based on the school they will attend. If we consider data on girls' involvement in STEM subjects in primary or middle school, we find this age range to be less open. This is the age at which these trends begin to manifest, as discussed by Banzato and Tosato, [2] "Several studies show that the differences between males and females begin to emerge in the transition of children from primary to secondary school" (p. 315).

The social expectations passed on by society and their families induce many girls to choose secondary schools on the basis of perceived opportunities for future employment. As support for working mothers is painfully inadequate in Italy, girls, consciously or otherwise, perceive that jobs and careers in technical and scientific sectors will make raising a family difficult, if not problematic [3].

Hence, the prophecy comes true: even girls who are good at mathematics or science, gradually turn away from engineering and physics towards a career in teaching, or the braver among them choose medicine, instead. 
For girls and women, teaching is seen as a chance to combine work and a private life: part-time work with less career pressure.

In our case, the glass ceiling metaphor represents the invisible, transparent barriers that prevent girls from undertaking courses and careers in the technical and scientific sectors. So-called role models, that is, successful women in the fields of science and technology or entrepreneurship, are often so far removed from the average person and so unreachable that reference to them is sometimes discouraging. If you have to be a wonder woman to sign up for physics, how can normal girls break through the glass ceiling?

On the other hand, Italian families offer a disarming picture of what it means to be skilled in STEM subjects: the advice-which is unthought-of and unrelated to reality, which often comes from the families themselves-is that technical studies open up more opportunities for employment.

An overview of the situation in Italy will clarify many aspects.

The OECD Report "Education at Glance 2017/An eye on education" indicates that only $18 \%$ of Italians are graduates and in subjects not very closely related to economic developments. The OECD places Italy in second last place, only ahead of Mexico, whereas the average in the 35 most influential countries is $37 \%$ graduates [4].

\section{A Multi-faceted Approach to a Complex Problem}

As we can see, there are various reasons for the lack of women in Italy involved in technical and scientific fields and the solutions to these are not quick and simple.

School is often inaccurately thought to be the primary cause of girls' disaffection with STEM subjects. However, while it may not be the primary cause, school is certainly an important source of the problem.

For years, Italian schools have had projects dedicated to promoting STEM subjects among girls, whereas associations and centers for Girls in STEM, Girls for Coding have sprung up in society at large.

In 2008, Scuola di Robotica brought the Roberta project to Italy, aimed at getting girls to discover robots. The Roberta project was begun by the Fraunhofer Institute in Bonn, and is dedicated to developing a methodology for girls in STEM, using educational robotics [5].

The Roberta methodology included phases in which the genders were separate in the first few hours of the course. This was to enable the girls to learn to code the robot on their own, without, as often happens, delegating the technical aspects to their male counterparts. After this, male and female participants worked together again. Since the girls did not like football, competitions with robots or "robot wars", the mission of Roberta robots was to simulate the behavior and communication of animals. One of the best known missions was the "flight of the bees", where several robots simulated communication between bees informing their companions where there were many flowers. 


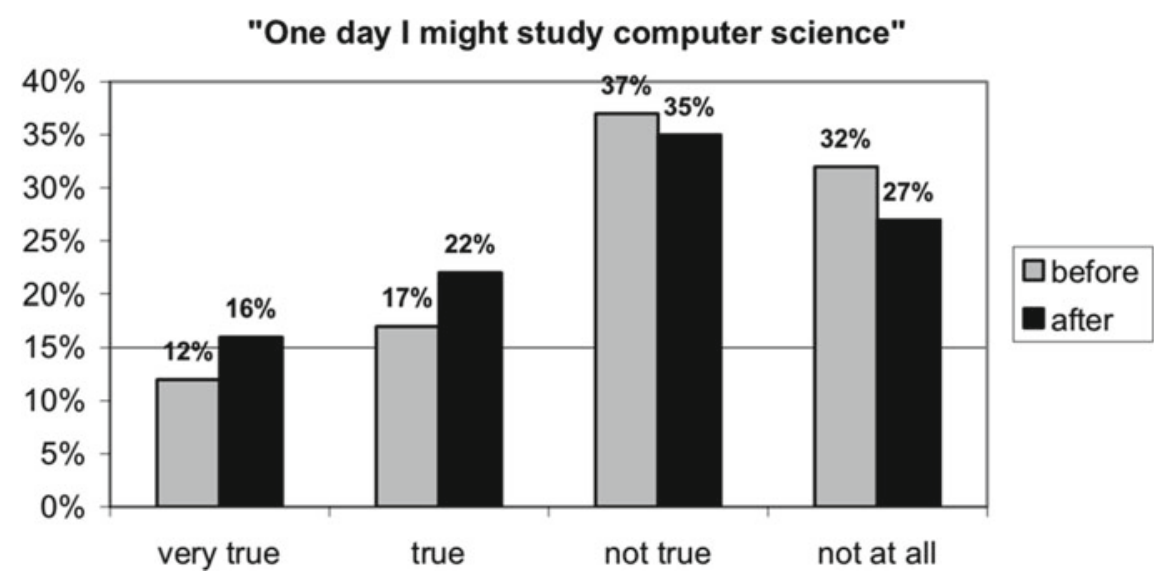

Fig. 1 Students' answers before and after a Roberta course $(\mathrm{N}=499)$

In 2007, the University of Bremen was tasked with evaluating the project's scalability and impact, with excellent results. In addition, many of the girls who participated in Roberta chose to study science. The table shows students' comments on the statement "I could study computer science", before and after participating in Roberta (Fig. 1).

The Roberta project and the many others that have been conducted in Italy to promote STEM among girls have shown that educational robotics is an excellent tool for this objective. Designing, building and programming a small robot involves many cognitive and social skills, and all students can in some way contribute to the project, which is a shared, group project.

\section{Conclusion}

Returning to our question, what do these data tell us? Why do we need them?

Stereotypes affecting educational choices restrict the freedom of both female and male students.

It is important to reflect on how educational choices are made and how they are affected by stereotypes. This enables us to broaden the spectrum of what is "thinkable" for male and female students alike, and removes the obstacles that limit their freedom of choice.

In addition to this, there are important consequences for the future of employment. The number of jobs in ICT will increase, and the low quantities of women in these sectors will have a strong impact on the availability of skilled workers, as well as increasing the gender gap [6]. Moreover, the new jobs of the future seem to go in the direction of greater interdisciplinarity, requiring more cross-disciplinary transversal 
skills compared to traditional sectorialization: one more reason to work towards getting rid of stereotypes.

Learning to program a robotics kit at school certainly does not solve the problems in the Italian economic and social structure we have mentioned, but if more girls and women happily face their fears and sense of inferiority with regard to mathematics and physics through educational robotics, perhaps we will have more sensitive women able to deal with the problems we will see in the near future.

\section{References}

1. Biemmi, I.: Gabbie di genere, retaggi sessisti e scelte formative. Rosenberg \& Sellier, Turin (2016)

2. Banzato, M., Tosato, P.: Narrative learning in coding activities: gender differences in middle school. Formazione e insegnamento 1, 339-354 (2017)

3. Ballona, E.S., Taviani, S.: Le Equilibriste. La maternità in Italia, save the children. https://s3. savethechildren.it/public/files/uploads/pubblicazioni/le-equilibriste-la-maternita-italia_1.pdf (2019). Last access October 2019

4. AAVV, OECD's annual education at a Glance. https://www.oecd-ilibrary.org/education/educat ion-at-a-glance-2017_eag-2017-en (2019). Last access October 2019

5. Hartmann, S., Wiesner, H., Wiesner-Steiner, A.: Robotics and gender: the use of robotics for the empowerment of girls in the classroom. In: Zorn, I., et al. (eds.) Gender Designs IT. Construction and Deconstruction of Information Society Technology. Springer Link (2007)

6. Berra, Cavaletto: Scienza e tecnologia. Superare il gender gap. Ledizioni, Turin (2019)

Open Access This chapter is licensed under the terms of the Creative Commons Attribution 4.0 International License (http://creativecommons.org/licenses/by/4.0/), which permits use, sharing, adaptation, distribution and reproduction in any medium or format, as long as you give appropriate credit to the original author(s) and the source, provide a link to the Creative Commons license and indicate if changes were made.

The images or other third party material in this chapter are included in the chapter's Creative Commons license, unless indicated otherwise in a credit line to the material. If material is not included in the chapter's Creative Commons license and your intended use is not permitted by statutory regulation or exceeds the permitted use, you will need to obtain permission directly from the copyright holder.

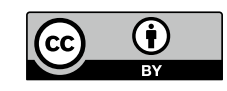

